\title{
NAZARIYYT
}

Yunus Cengiz.Doğa ve Öznellik:Câhız’nnAhlâkDüşüncesi [Nature and Subjectivity:Al-Jāhiz’s Ethical Thought]. Istanbul: Klasik Yayınlar1, 2015. 298 pages. ISBN: 9786055245801.

\section{Ömer Türker*}

\section{Translated by Hasan Talha Soysal **}

This work, which examines the ethical thought of the famous theologian and scholar of literature al-Jāhiz (d. 255/869), consists of an introduction and three chapters. The introduction discusses al-Jāhiz's sources of ethical thought and its originality, along with the research methodology, and describes the concepts of nature and subjectivity that make up the title. According to Yunus Cengiz, what alJahhiz means by nature is that all actions done by humans take place in a natural way, as for the subjectivity he means that humans can intervene in this natural process and thereby construct oneself. Thus, each subject's construction will be inevitably unique. Hence subjectivity is used not in its common meaning, but with reference to thinkers such as Michel Foucault (d. 1984) and Gilles Deleuze (d. 1995).

In the first chapter, the soul-body relation in al-Jāhiz's thought is analyzed. The author emphasizes that two sources played a significant role in his idea of the soul: the medicine of Galen (d. ca. 200) and the theory of physics proposed by al-Nazzām (d. 231/845). According to Cengiz, al-Jāhiz, while moving from the theories of latency (kumūn) and appearance (zuhür), analyzed those tendencies in the soul that are in a constant conflict and thus highlighted the influence of the body over ethics. These tendencies entered his ethical thought in a hierarchical way and share three primary natures in themselves: sexuality, nourishment, and communication. In this regard, the discussions in the book show that al-Jāhiz's analysis about sexuality and communication deserve to be researched separately. One of this section's notable points is the way in which the author shows how al-Jāhiz adopted and applied al-Nazzāam's theories of latency and appearance to an ethical theory and transformed it into a socio-scientific explanatory model.

* Prof. Dr., Marmara University, Faculty of Theology. Correspondence: om.turker@gmail.com.

** Undergraduate Student, Istanbul Şehir University, School of Islamic Sciences. 
In the second section, Cengiz argues that al-Jāhiẓ's ethical thought places the influence of emotional states (e.g., lust, pleasure, and joy) over that of knowledge. Here, the author seeks to crystallize how al-Jāhiz perceived the relation of ethics and knowledge so that he can evaluate knowledge in three stages: senses, the formation of memory, and mental intuition. According to this, lust, fear and the moral faculties formed by these emotions accompany all knowing activities and, furthermore, constitute the basis of thinking. Therefore, authentic knowledge can only arise in one who possesses a balanced personality and good ethics. The author concludes that due to the relation that al-Jāhiz established between emotions and knowledge, ultimate knowledge would be obtained through intuition. The most striking aspect of this section is the following: In Islamic thought, the knowledge-ethics relationship put forward and studied by the Sufis and ascetics was transformed into a separate and more profound theory by a Mu'tazili scholar using the sources of the philosophical and theological traditions.

In the third chapter, Cengiz studies al-Jāhị s presentation of the processes through which moral faculties are gained, the faculty-behavior relation, and the goal of ethics. This chapter examines the circumstances of ethics in terms of concepts such as imagination, reason, pleasure, joy, altruism, and second nature. According to al-Jāhịiz, in this context reason and imagination help human being to attain contentment through the imagination of pleasure. In fact, this contentment corresponds to joy that is the purpose of ethics. But al-Jāhiz establishes a relation between joy and gratitude via the concept of pleasure: As human beings contemplate pleasure, they will come to see the blessing that they are enjoying and thus show gratitude to the one who bestowed it upon them.

According to him, each human being is equipped with the faculties of desire and reason because their ensuing conflict generates the subjectivity explained in the introduction. The outcome can only be the domination of desire or reason, or a balance between them. At first glance one might think that al-Jāhị would prefer the balanced state; however, according to him such a state is worrisome. Hence, ethically appropriate actions would be those in which reason overrides desire. AlJāhiz thinks that such actions can be realized through altruism, meaning that they are done without any external force and effort directed toward them, and only with love toward the mental ones. Reaching this rank brings about the ethical subject's "second nature."

The author draws attention to two important issues: 
(1) Al-Jāhịị’s ethical theory considers certain moral states (e.g., arrogance, humility, cowardice, and bravery) as good or evil with respect to the surrounding circumstances. For example, arrogance and humility are not good or evil in all cases. This is one of the most important claims of his ethical theory about perfecting a human being through the moral faculties. Also noteworthy is that it can be further deepened by establishing a relation with the Mu'tazilì Abū Hāshim al-Jubbā'î's (d. 321/933) theory of wujūh. Considering that the inheritance of the Greek philosophers provides a hierarchy of fixed virtues, the distinctness of alJāhiz's ethical thinking, especially that part fed by Islamic sources, can be noticed. As a matter of fact, the Sufi tradition considerably deepened the view that virtues are dynamic meanings, for, as they say, the favors of those who are good are, in fact, evil compared to [those] who are brought closer to Allāh. In other words, the people's ethical choices earn their value in regard to their distance from Allāh. Hence, the meaning realized within a certain pattern of action is not fixed, but dynamic. So in this context, it is quite favorable to deepen the relation between the Sufi view of dynamic meanings and al-Jāhiz's thesis that virtues are subject to change with respect to the surrounding circumstances.

(2) Al-Jāhị considers human circumstances such as writing, speaking, and humor as tools by which one can acquire ethics. For this reason, Cengiz emphasizes that al-Jāhiz encourages actions that empower a human being's ethical status. These implicit highlights, which can be considered a result of this figure's literary personality, cover his rather different and unique aspect. This is so because al-Jāhiz takes many human circumstances that are usually not discussed in books on ethics and whose contribution to ethical life is not analyzed as part of the process of attaining human perfection.

Although he was regarded as an important scholar in the Mu'tazili tradition, al-Jāhiz is not a typical theologian because being also a literary figure he wrote his texts in a literary style and thus articulates thoughts both in different literary arts and in quite different places. For this reason, in Turkey he is more famous for his literary personality. As Eşref Altaş of Istanbul Medeniyet University said in a session we held on this book, "Yunus Cengiz presents al-Jāhị as a thinker in Turkish in the true sense of the word." In this context, the book is very successful in extracting a theory from the scattered narratives of al-Jāhiz’s literary texts. The ethical thought of al-Jāhị has been put forward as a holistic theory that can be summarized with the concepts of fundamental natures, subjectivity, second nature, pleasure, joy and gratitude. 
One remarkable aspect of the book is the translations from al-Jāhị's texts. Those who know their literary power will appreciate how difficult their translation is. In Cengiz's book, they seem so beautiful and perfect that they cannot escape the reader's attention. Honestly, when I was reading the book I wished that the author would have translated at least a few of the basic treatises of al-Jāhiz to Turkish.

This book does contain certain gaps, however. Since Cengiz regards al-Jāhịiz as part of a philosophical tradition, references to the various theological traditions are weak. One would expect such references to be stronger, given that Cengiz studied Qāẹī 'Abd al-Jabbār's (d. 415/1025) action theory in his dissertation and dedicated significant amount of his intellectual efforts to understanding and interpreting the Mu'tazili tradition, ${ }^{1}$ although the book states that one of the fundamental sources of al-Jāhiz's ethical theory is al-Naẓāam's theory of physics. However, al-Jāhiz's ethical thought became such a successful theory that it managed to transform the concepts of philosophical tradition with Mu'tazili tradition's fundamental principles. In particular, the concept of joy (surūr), which is presented as the apogee of his ethical thought, and the principle of gratitude both have a purely Mu'tazili origin. If we overlook the sensitivities of $\mathrm{Mu}$ 'tazili theology, we cannot recognize his critical and transforming actions upon both Islamic ethical thought and the ethical legacy inherited from the Greek tradition. Indeed, al-Jāhịiz's reading of Aristotle's (d. 322 BCE) ethical theories, which was conducted through a Mu'tazili thesis, in one aspect resembles al-Rāghib al-Ișfahānī's (d. ca. 502/1108) reading of Aristotle's ethical theory in the Sunni theological tradition.

Al-Ișfahānī made the Neoplatonian soul theory and Aristotelian virtue theory as part of a new ethical theory that takes the theories of acquisition (kasb) and guidance (hidāya) as its basis. Similarly, al-Jāhiz took the theology and ethical principles developed by Mu'tazilī theories as a basis and made the Aristotelian soul and virtue schemas part of a new moral thought. It seems that by doing so he constructed an even more extensive moral theory. There is no doubt that alJāhiz’s literary genius made a huge contribution to the extent and diversity of this construction. 